\title{
Religious Cliché and Stigma: A Brief Response to Overlooked Barriers in COVID-19 Management
}

\author{
Furqan K. Hashmi ${ }^{1} \cdot$ Qaiser Iqbal $^{2} \cdot$ Naheed Haque $^{2} \cdot$ Fahad Saleem $^{2} \odot$
}

Published online: 8 July 2020

๑) Springer Science+Business Media, LLC, part of Springer Nature 2020

\begin{abstract}
For decades, religion has provided explanations and answers to existential questions and queries that can emerge during a pandemic. This characteristic of religion has helped communities in finding answers and meanings to their confusions. During a pandemic, healthcare professionals are often unprepared in answering the patients' religious beliefs regarding the diseases. Moreover, patients are faced with religious clichés and stigma that results because of religious beliefs and practices. To overcome the religious stigma, a deeper understanding of religious beliefs and values is required so that a perception or practice change can take place. Therefore, the inclusion and collaboration of spiritual leaders with healthcare professionals are needed to ensure a holistic understanding and overcome the stigma that can shape as a barrier for reaching an optimal therapeutic outcome.
\end{abstract}

Keywords Religious cliché · Stigma · Barrier · COVID-19

\section{Introduction}

The COVID-19 is a global crisis, and efforts are focused concomitantly on limiting the transmission and reducing the impact of the virus (World Health Organization 2020b). From hand hygiene to vaccine development, the world is striving hard to explore an effective and efficient disease management protocol against the COVID19. However, like every other disease, the COVID-19 has developed a religious cliché and stigma that is shaping as a potential barrier to disease prevention and management. Religion and faith are part of the human makeup, and for that very reason, faith healing exists in societies as one of many philosophies.

Fahad Saleem

fahaduob@gmail.com

1 University of the Punjab, Lahore, Punjab, Pakistan

2 University of Balochistan, Quetta, Balochistan, Pakistan 


\section{Faith-Based Practices}

Shifting our concerns to the religious cliché and COVID-19 management in developing countries, certain faith-based practices have resulted in avoiding the established precautionary measures against the disease (World Health Organization 2020a). Correlating with our argument, a group of Islamic faith believers avoided the recommended precautions by referring to the Holy Quran; "Allah is sufficient for us; and what an excellent guardian He is" (The Noble Qur' an 2016b). Additionally, the prevailing belief of life and death is controlled by the Almighty also shaped as a religious stigma in adopting precautionary measures against the COVID-19 (The Noble Qur' an 2016a). In the very context, drinking cow urine and hosting cow urine drinking parties as a potential treatment for COVID-19 were also reported (BBC News 2020; Irish 2020). It was further believed that cow urine has immunity-boosting and virus-eradicating properties and hence was sprinkled in certain areas as a potential disinfectant leaving alone the concept of social distance and communal hygiene (Ghosh 2020).

Continuing with the examples of such faith-based practices, combining and consuming water and sacred soil found at the grave of Maronite monk Mar Charbel (Mount Lebanon) was also observed against COVID-19. Moreover, healthcare officials were approached by the people proposing to acknowledge the soil-based treatment and to use it against COVID-19 infection (Darwias 2020). In certain areas of the globe, COVID-19 was related to gay pride events. It was claimed that the COVID-19 is divine retribution for gay pride parades and the disease will not hit the Arab countries as they don't have these episodes and practices (Staff 2020).

Although there are no scientific or evidence-based data to support the abovestated claims and unlikely to be, we also cannot deny that faith-based practices and beliefs have sometimes resulted in "miracles" producing significant change. Consequently keeping in mind the substantial influence of religion on people and subsequent communities, we are proposing a collaborative model between religious communities and healthcare providers/policymakers to manage the COVID-19. Our suggestion is based on two observations. Across the world, religion influences all sorts of health behaviors and it can play a major role in the medical decisions that people make (Carey and Cohen 2009; Koenig 2004). In agreement with what we are proposing, Koenig mentioned "Faith in God" as the second most important factor while discussing the list of influential factors during a course of treatment (Koenig 2003). In a nutshell, religion and faith can contribute substantially during this time of global crisis and we must take advantage of this resource to promote health education and precautionary measures against COVID-19.

\section{Religion and Health Promotion}

An important question is how to considerately and correctly take advantage of this resource (religion) in promoting health awareness and to manage the COVID-19. As argued by Miller and Rubin (2011) when referring to the AIDS epidemic, one 
possible solution is to engage the religious leaders of the respective societies and communities as frontline professionals (Miller and Rubin 2011). Religious leaders are some of the most respected figures in many communities, and their influence on their followers can greatly benefit the efforts against COVID-19. The same influence should be utilized to raise awareness and change the attitudes and practices of the community dwellers. As community members listen to their religious leaders, healthcare organizations should take religious leaders on board while handling and managing the COVID-19. Daily services, weekly sermons or specialized COVID19-based orations delivered by whatever means possible should be arranged and must be utilized in disseminating precautionary measures and to follow evidencebased practices against the COVID-19. This is attainable by adopting the training of trainers (ToT) model that is a strong predictor of sustainability because of its potential for up-skilling the workforce rapidly and economically (Mormina and Pinder 2018).

\section{Conclusion}

Given that religious leaders can and have influenced social values, practices, and beliefs with their faith-based teachings, we strongly believe that their inclusion in health promotion and (if suitably qualified as trained chaplains) their inclusion as part of the healthcare team will result in holistic care that is more proficient and acceptable as compared to non-inclusive health care. The COVID-19 is a pandemic catastrophe, and we have to use every possible option that is available in limiting the transmission of the disease and overcome the religious cliche and stigma that is shaping as a barrier in the optimal management of the COVID-19.

\section{Compliance with Ethical Standards}

Conflict of interest There is no conflict of interest to declare.

\section{References}

BBC News. (2020). Coronavirus: Is drinking cow urine any help? Accessed 5 April 2020, from https:// www.bbc.com/news/world-asia-india-51910099.

Carey, L. B., \& Cohen, J. (2009). Religion, spirituality and health care treatment decisions. Journal of Health Care Chaplaincy, 15(1), 25-39.

Darwias, R. (2020). Sacred soil, cow urine and other rituals: People turn to religion to deal with the corona virus. Retreived 7 April, 2020, from https://www.albawaba.com/node/sacred-soil-cow-urine -and-other-rituals-people-turn-religion-deal-coronavirus-1345263.

Ghosh, S. (2020). Can cow urine cure Coronavirus? Four of the most ridiculous myths about COVID-19 busted. Retreived 8 April, 2020, from https://www.edexlive.com/news/2020/mar/18/can-cow-urine -cure-coronavirus-four-of-the-most-ridiculous-myths-about-covid-19-busted-10747.html.

Irish, J. (2020). Coronavirus: Hindu group hosts 'cow urine drinking party' to cure illness despite lack of evidence. Accessed 8 April, 2020, from https://www.independent.co.uk/news/world/asia/coronaviru s-news-hindu-cow-urine-drinking-party-india-a9402491.html. 
Koenig, H. G. (2003). Health care and faith communities: How are they related? Journal of General Internal Medicine, 18(11), 962-963.

Koenig, H. G. (2004). Religion, spirituality, and medicine: Research findings and implications for clinical practice. Southern Medical Journal, 97(12), 1194-1200.

Miller, A. N., \& Rubin, D. L. (2011). Health communication and faith communities. Sudbury: Hampton Press.

Mormina, M., \& Pinder, S. (2018). A conceptual framework for training of trainers (ToT) interventions in global health. Globalization and Health, 14(1), 1-11.

Staff, T. (2020). Israeli rabbi: Coronavirus outbreak is divine punishment for gay pride parades. Retreived 9 April, 2020, from https://www.timesofisrael.com/israeli-rabbi-blames-coronaviru s-outbreak-on-gay-pride-parades/.

The Noble Qur'an. (2016a). Surah Ali ‘Imran 3:156: Pro Bono Project, New Orleans, LA.

The Noble Qur'an. (2016b). Surah Ali ‘Imran 3:173: Pro Bono Project, New Orleans, LA.

World Health Organization. (2020a). Coronavirus disease (COVID-19) advice for the public. Retreived 9 April 2020, from https://www.who.int/emergencies/diseases/novel-coronavirus-2019/advice-forpublic.

World Health Organization. (2020b). Report of the WHO-China Joint Mission on Coronavirus Disease 2019 (COVID-19). Retreived 5 April, 2020, from https://www.who.int/docs/default-source/coron aviruse/who-china-joint-mission-on-covid-19-final-report.pdf.

Publisher's Note Springer Nature remains neutral with regard to jurisdictional claims in published maps and institutional affiliations. 